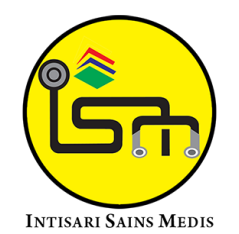

Published by Intisari Sains Medis

\section{Glioma saraf optik sebagai perluasan dari glioma cerebrii: sebuah laporan kasus}

\author{
Anak Agung Ayu Surya Nirmala Dewi ${ }^{1 *}$, Putu Yuliawati ${ }^{2}$, Ni Made Laksmi Utari ${ }^{3}$, \\ Anak Agung Ayu Sukartini Djelantik ${ }^{4}$, I Made Agus Kusumadjaja ${ }^{5}$
}

1PPDS-1 Bagian/SMF IImu Kesehatan Mata Fakultas Kedokteran Universitas Udayana/Rumah Sakit Umum Pusat Sanglah Denpasar, Bali-Indonesia; 2,3,4,5Departemen/KSM IImu Kesehatan Mata Fakultas Kedokteran Universitas Udayana/Rumah Sakit Umum Pusat Sanglah Denpasar, BaliIndonesia;

\footnotetext{
*Korespondensi:

Anak Agung Surya Nirmala Dewi;

PPDS-1 Bagian/SMF IImu Kesehatan Mata Fakultas Kedokteran Universitas Udayana/Rumah Sakit Umum Pusat Sanglah Denpasar, Bali-Indonesia; ayusuryand@gmail.com
}

\begin{abstract}
Introduction: Optic Nerve Gliomas (ONG) are the most common primary Cerebral Nervous System tumor in childhood with greatest tendency for growth in the first 3-5 years of life (Huang, 2020). Most children diagnosed with ONGs have neurofibromatosis type 1 (NF-1) (Simmons,2013) with painless and slowly progressive decreace of vision. Imaging investigation with CT-scan or MRl is important to diagnose patient with ONG. The aim of this paper is to report a case of optic pathway glioma resulting rapid death of a child.

Case Illustration: A 7-year-old girl complained that her eyes could not see in the past 1 year and protrusion with a white spot that is getting wider in the middle of the eye on her right eye since 3 months ago. Her left eye could not see in the past 3 weeks. She also complained about pain on her head. From ophthalmology examination visual acuity both eyes are no light perception. On her right eye we found protrusion with scleral show and lagophthalmos on her right eye, periconjunctival injection with corneal edema, deep anterior chamber and IOP 47 . On the left eye we found midilated pupil with decreased reflex and the posterior segment we found optic nerve head hazy demarcated, cup-disc ratio difficult to be evaluated,

good retina, decreased macular reflex and macular star (+). From right eye USG we found severe vitreous opacity. The MRI result from June $15^{\text {th }} 2020$ is suggested for optich pathway glioma dd/ pylocystic astrocytoma and suspected expand to internal auditory canal dextra. The patient was diagnosed with OD Proptosis ec retrobulbar tumor susp optic nerve glioma that expand from chiasma / cerebrii + vitreous bleeding+secondary glaucoma. OS Optic Nerve Edema ec intracranial mass. The patient was planned for $\mathrm{OD}$ extended enucleation join op Tumor Removal from Neuro Surgery under General Anesthesia. However, the surgery was postponed due to unstable condition and patient died from septic shock 2 months after the first arrival at the eye clinic.

Conclusion: Optic Nerve Glioma are the most common primary Cerebral Nervous System tumor in childhood. This patient came with decrease of vision, protrusion on her right eye and pain with MRI finding suggested for optic nerve glioma. This patient should have done surgery but her condition was unstable. Good handling and multidisciplinary cooperation in the diagnosis and management of intraocular and intracranial masses are needed to provide a good outcome for the patient.
\end{abstract}

Keywords: glioma, optic, treatment, case.

Cite This Article: Dewi, A.A.A.S.N., Yuliawati, P., Utari, N.M.L., Djelantik, A.A.A.S., Kusumadjaja, I.M.A. 2021. Glioma saraf optik sebagai perluasan dari glioma cerebrii: sebuah laporan kasus. Intisari Sains Medis 12(3): 986993. D0I: $10.15562 /$ ism.v12i3.1129

\section{ABSTRAK}

Pendahuluan: Glioma Saraf Optik (GSO) merupakan tumor otak primer yang paling banyak terjadi pada 1 dekade kehidupan dengan kecenderungan terjadi pada usia 3-5 tahun. Anak-anak yang didiagnosa dengan GSO biasanya memiliki neurofibromatosis tipe 1 (NF-1) yang timbul secara sporadik. GSO memiliki gejala penurunan penglihatan tanpa adanya rasa nyeri yang dirasakan perlahan. Pemeriksaan penunjang dalam menegakkan diagnosis GSO bisa menggunakan (T-scan ataupun MRI. Tujuan dari makalah ini adalah untuk melaporkan sebuah kasus bagaimana cara mendiagnosa glioma saraf optic pada anak-anak.

Ilustrasi kasus: Pasien perempuan, 7 tahun, datang
(2 Juni 2020) dengan keluhan kedua mata tidak dapat melihat sejak 1 tahun yang lalu dan mata kanan menonjol sejak 3 bulan disertai bintik putih yang semakin melebar di bagian tengah mata. Mata kiri dikatakan tidak bisa melihat sejak 3 minggu yang Ialu. Nyeri kepala sering dikeluhkan oleh pasien di seluruh kepala. Pemeriksaan oftalmologi didapatkan visus kedua mata no light perception (NLP), proptosis dengan scleral show dan lagoftalmos $2 \mathrm{~mm}$ pada mata kanan. Konjungtiva mata kanan didapatkan injeksi perikorna dengan edema kornea. Bilik mata depan mata kanan kesan dalam. Tekanan intraokular mata kanan $47 \mathrm{mmHg}$. Middilatasi dengan penurunan reflek 
pupil didapatkan pada mata kiri, lensa jernih dan pada pemeriksaan segmen posterior didapatkan papil nervus optik batas kabur, cup-disc ratio (CDR) sulit dievaluasi, retina kesan baik, reflex makula menurun dengan macular star. Hasil USG mata kanan didapatkan kesan kekeruhan vitreous berat. Pada 15 Juni 2020 pasien dilakukan MRI dengan kesan mengarah pada optic pathway glioma $\mathrm{dd} /$ pylocytic astrocytoma dan suspek perluasan ke regio internal auditory canal dextra. Pasien didiagnosis dengan OD proptosis ec tumor retrobulber susp glioma saraf optik yang berasal dari chiasma / cerebri + perdarahan vitreus + glaukoma sekunder, OS Papil edema ec massa intracranial dan direncanakan OD extended enukleasi join op tumor removal oleh Bedah Saraf dengan General Anestesi. Namun, pasien belum dilakukan operasi karena keadaan pasien memburuk dan meninggal akibat syok sepsis 2 bulan pasca kedatangan pertama ke poli mata.

Simpulan: Glioma saraf optik merupakan tumor yang sering ditemukan pada anak-anak. Pada pasien sudah didapatkan nyeri, penurunan tajam penglihatan dan proptosis serta gambaran MRI yang mendukung diagnose glioma saraf optic. Sebaiknya pasien dilakukan tindakan pembedahan namun keadaan umum pasien tidak memungkinkan. Penanganan yang baik dan kerjasama multidisiplin dalam penegakan diagnosis dan tatalaksana massa intraocular maupun intracranial dibutuhkan untuk memberikan luaran yang baik bagi pasien.

Kata kunci: glioma, optik, terapi, kasus.

Sitasi Artikel ini: Dewi, A.A.A.S.N., Yuliawati, P., Utari, N.M.L., Djelantik, A.A.A.S., Kusumadjaja, I.M.A. 2021. Glioma saraf optik sebagai perluasan dari glioma cerebrii: sebuah laporan kasus. Intisari Sains Medis 12(3): 986993. D0I: 10.15562/ism.v12i3.1129

\section{PENDAHULUAN}

Glioma Saraf Optik (GSO) merupakan tumor otak primer yang paling banyak terjadi pada dekade pertama kehidupan. ${ }^{1}$ GSO merupakan low-grade neoplasma yang bisa berinfiltrasi ke nervus optikus, kiasma optic, traktus optikus dan hipotalamus. GSO terjadi pada awal masa kanak-kanak dengan kecenderungan terjadi pada usia 3-5 tahun. Lima persen kejadian tumor intracranial pada anakanak merupakan GSO. Anak-anak yang didiagnosa dengan GSO biasanya memiliki neurofibromatosis tipe 1 (NF-1) yang timbul secara sporadic. Diperkirakan NF-1 terjadi pada 2500-3000 orang di dunia. $^{2}$ Anak dengan Glioma biasanya berusia kurang dari 10 tahun dengan ratarata usia 8.8 tahun. $^{2}$

Low Grade Glioma merupakan tumor yang berasal dari sel glia yang memiliki karakteristik heterogen dan berbatas tegas. Sebagian besar GSO memiliki gambaran histologi yaitu juvenile pilocytic astrocytomas (WHO Grade I Tumors). Gambaran khas yang dapat dijumpai adalah adanya Rosenthal fibers. Produksi gen NF-1 yang tidak cukup dan adanya functional neurofibromin akan menghasilkan disregulasi sinyal RAS sehingga meningkatkan proliferasi sel dan pembentukan tumor. Sebuah duplikasi yang kecil dari gen 7 q34 juga didapatkan pada mayoritas pilocytic astrocytomas. Duplikasi ini juga melibatkan BRAF yang diketahui sebagai oncogene yang berperan pada berbagai kanker. Glioma muncul dari astrocytes nervus optikus dan visual pathway. Astrocytes yang berproliferasi ini menyebar melalui pia mater, arachonid dan subarachnoid space dimana fibrovascular dan sel meningeal mengalami proliferasi. Proses ini disebut dengan arachnoidal hyperplasia yang apabila bertambah dapat menimbulkan pembesaran tumor. ${ }^{1}$

GSO memiliki gejala penurunan penglihatan tanpa adanya rasa nyeri yang dirasakan perlahan. Penurunan penglihatan ini termasuk tajam penglihatan, lapang pandang, kontras dan penglihatan warna. ${ }^{2}$ Gangguan gerak bola mata terjadi pada $30 \%$ kasus GSO, selain itu pasien akan mengeluh nyeri kepala, kejang, mual muntah, pertumbuhan yang terhambat dan retardasi mental. ${ }^{1}$ Apabila gejala tersebut terjadi asimetris, maka kita akan menemukan Relative Afferent Pupilary Defect (+) dan strabismus sensoris serta proptosis. Optik Atrofi bisa digunakan sebagai penanda prognosis dari GSO. Perluasan tumor ke intrakranial bisa terjadi, GSO dapat meluas ke hipotalamus dan terjadi gangguan endokrin. ${ }^{2}$ Peningkatan tekanan intra kranial, penurunan fungsi hipotalamus dan kelenjar pituitary menunjukkan terjadinya suatu proses intracranial. Hidrosefalus bisa terjadi apabila tumor sudah menyebar ke kiasma optikus. Tumor yang menyebar ke hipotalamus akan menyebabkan gangguan pubertas, gangguan hromon pertumbuhan, gangguan hormone gonadotropin (TSH dan ACTH). ${ }^{1}$

Pemeriksaan yang bisa dilakukan antara lain MRI kepala dan orbita. ${ }^{1}$ Gambaran khas dari GSO antara lain gambaran fusiform, pembesaran nervus dan kiasma optikus yang diffuse, adanya downward kink pada mid-orbit serta kanalis optikus yang membesar. Degenerasi kistik juga bisa ditemui pada hasil MRI. Biopsi pada lesi yang dicurigai biasanya tidak perlu dilakukan karena neuroimaging sudah bisa mendiagnosis. ${ }^{3}$

Penanganan GSO saat ini kontroversial. Sebagian besar kasus stabil dan memiliki progresifitas lambat. Keputusan melakukan terapi harus diambil dengan hati-hati dan berbeda pada setiap kasusnya. Pasien dengan pertumbuhan intraorbital tumor yang pesat bisa dilakukan operasi untuk mengisolasi tumor agar tidak menyebar hingga kiasma optikus. Eksisi tumor dipertimbangkan pada pasien yang mengalami proptosis parah serta adanya expose dari kornea atau adanya chemosis. Kemoterapi menggunakan dactinomycin, vincristine, dan etoposide 
dilaporkan efektif dalam menghambat progessifitas chiasmal-hypothalamic gliomas. Kemoterapi dapat menurunkan kebutuhan radioterapi karena memiliki efek jangka panjang seperti gangguan pertumbuhan intelektual dan endokrin anak. Radioterapi disarankan apabila pasien tidak bisa menjalani operasi seperti lesi di chiasma atau tractus optikus dan mengalami perburukan gejala setelah dilakukan kemoterapi. ${ }^{3}$ Pasien GSO perlu dilakukan pemeriksaan mata setiap 2 tahun hingga pasien mencapai usia 18 tahun. Tidak ada prosedur MRI untuk individu yang asimptomatik. ${ }^{4}$

\section{LAPORAN KASUS}

Pasien seorang anak perempuan berusia 7 tahun datang ke poli mata divisi Pediatric Ophthalmology mengeluhkan kedua mata tidak dapat melihat. Mata kanan tidak dapat melihat sejak 1 tahun sebelum dilakukan pemeriksaan, kabur bersifat perlahan, hingga akhirnya tidak dapat melihat sama sekali. Awalnya mata kanan sempat merah dan terlihat ada bintik putih di bagian tengah mata. Mata kanan menonjol sejak 3 bulan yang lalu, dan mata kiri dikatakan mulai kabur sejak 3 minggu yang lalu. Keluhan mata berair, merah, maupun keluar kotoran di mata kiri disangkal. Riwayat nyeri kepala sering dikeluhkan oleh pasien di seluruh kepala. Riwayat keluhan serupa di keluarga disangkal. Riwayat kelahiran spontan, cukup bulan, namun ibu pasien lupa berapa berat badan lahir pasien. Riwayat imunisasi lengkap sesuai usia dan riwayat penyakit pada saat kehamilan disangkal. Riwayat alergi dan penyakit sistemik lain disangkal. Riwayat penurunan berat badan disangkal.

Pemeriksaan fisik mata awal pada tanggal 2 Juni 2020 di poli mata divisi pediatric oftalmologi didapatkan visus kedua mata No Light Perception (NLP). Pemeriksaan segmen anterior kedua mata didapatkan proptosis dengan scleral show dan lagoftalmos $2 \mathrm{~mm}$ pada mata kanan, sedangkan palpebra kiri normal. Konjungtiva mata kanan didapatkan injeksi perikorna dengan edema kornea (Gambar 1). Bilik mata depan mata kanan kesan dalam, namun pemeriksaan iris hingga segmen posterior sulit dievaluasi. Tekanan intraokular mata kanan 47
mmHg. Middilatasi dengan penurunan reflex pupil didapatkan pada mata kiri dengan lensa jernih dan pada pemeriksaan segmen posterior didapatkan papil nervus optik batas kabur, cup-disc ratio (CDR) sulit dievaluasi, retina kesan baik, reflex makula menurun dengan macular star. Dilakukan pemeriksaan USG untuk menilai segmen posterior mata kanan dan didapatkan kesan kekeruhan vitreous berat dengan refleksivitas sedang-tinggi dan mobilitas rendah, sedangkan kavum vitreous mata kiri dalam batas normal (Gambar 2). Pasien didiagnosa dengan Okuli Dextra (OD) proptosis non axial ec susp tumor inrtraokular dd tumor retrobulbar + glaucoma sekunder, Okuli Sinistra (OS) optic disc swelling ec susp infeksi. Pasien direncanakan untuk dilakukan pemeriksaan darah untuk work-
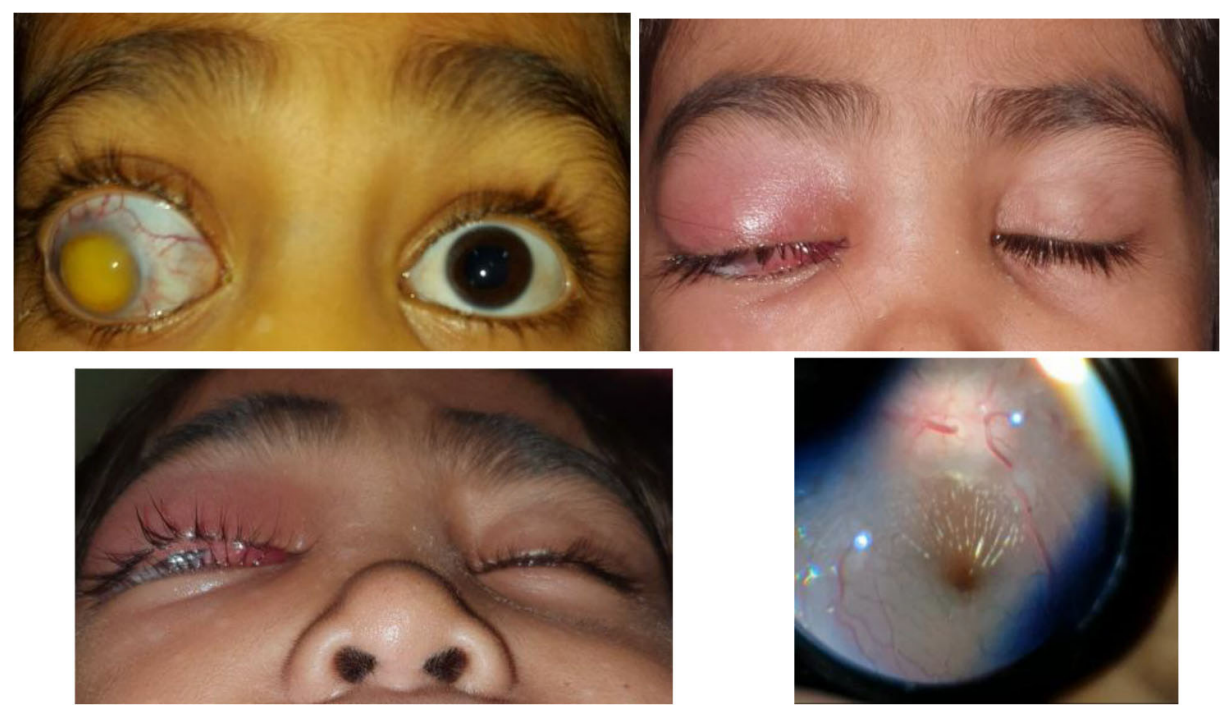

Gambar 1. Penampang mata kanan pasien dengan kondisi lagoftalmos dan proptosis pada saat menutup mata, serta adanya edema dan gambaran hemosiderin. Gambaran funduskopi mata kiri tampak gambaran macular star.
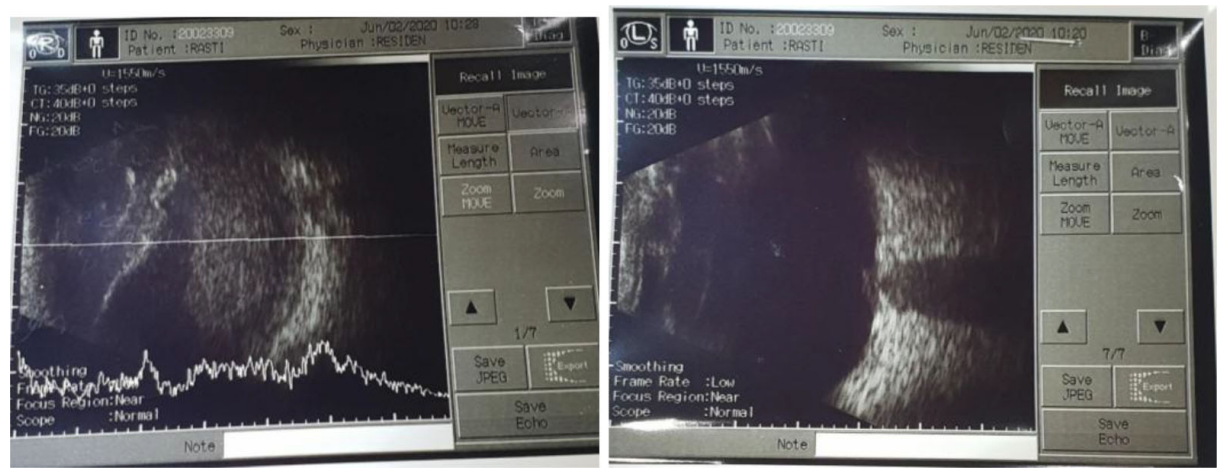

Gambar 2. Pemeriksaan USG mata kanan menunjukkan gambaran kekeruhan vitreous berat yang mengarah pada massa intraocular, sedangkan mata kiri dalam batas normal. 
yang tampak hipo-isointense pada T1WI, hyperintense sedikit pada T2WI, isointense pada fat sat, berukuran sekitar 4,6 x3,8 x 4,4 cm dengan komponen kistik minimal dengan penyangatan kontras kuat, tampak perluasan ke intraorbita, menekan ventrikel III. Tampak dilatasi dari ventrikel lateral disertai periventrikel cerebral edema (Gambar 3). Tampak pula gambaran lesi isointense TIWI, hiperintense sedikit pada T2WI yang menyangat yang mengesankan adanya perpanjangan massa jaringan lunak
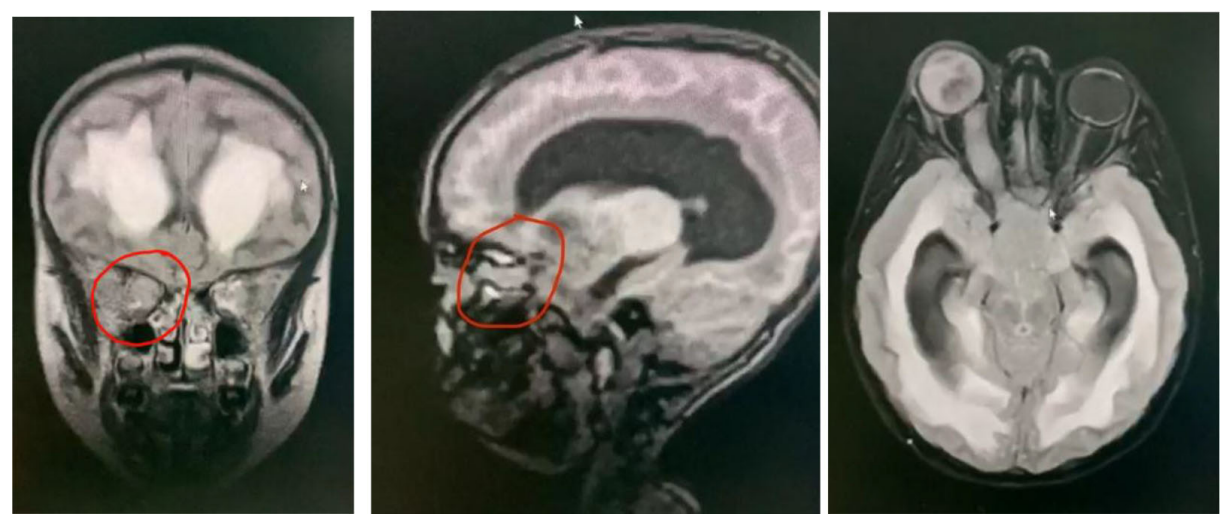

Gambar 3. Gambaran MRI kepala pasien tampak massa tumor pada nervus optikus dextra.
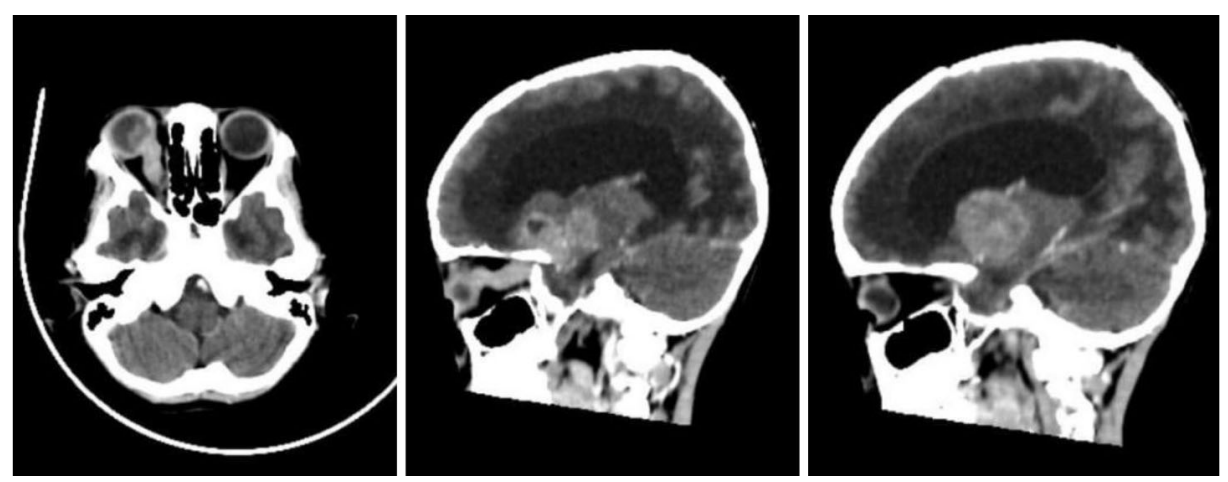

Gambar 4. Gambaran CT Scan kepala pasien tampak massa tumor pada regio pineal, suprasellar, dan parasellar yang mendesak Ventrikel III yang menyebabkan pembesaran ventrikel lateral kanan kiri. Tampak massa tumor intrabulbulus oculi dextra yang meluas ke nervus optikus, sinus cavernosus, suprasellar hingga regio pineal.
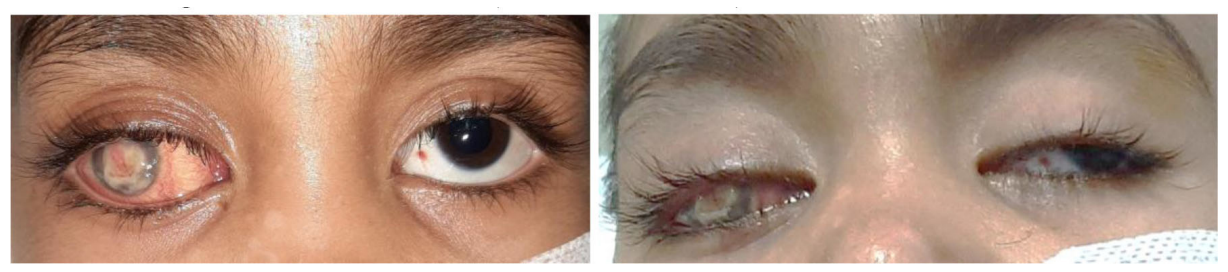

Gambar 5. Penampang mata pasien saat dirawat di PICU dengan ditemukannya lagoftalmos $1 \mathrm{~cm}$ di kedua mata dan proptosis non axial. glioma dd/ astrocytoma dan direncanakan untuk observasi sambil dikonsulkan ke Divisi Tumor.

Tanggal 16 Juni 2020 pasien dikonsulkan ke Divisi Tumor untuk direncanakan untuk enukleasi / eksenterasi dengan GA. Tekanan intra okular mata kanan ditemukan 47. Pasien didiagnosa dengan OD proptosis ec tumor retrobulber susp glioma saraf optik yang berasal dari chiasma / cerebrii + perdarahan vitreus + glaukoma sekunder, OS Papil edema ec masa intracranial dan direncanakan OD extended enukleasi join op TS Bedah Saraf dan konsul Departemen Bedah Saraf. Departemen Bedah Saraf mendiagnosa dengan Optic Pathway Glioma dd/ Polysitic Astrositoma + Hydrocephalus obstructive dan direncanakan untuk Tumor Removal join dengan TS Mata.

Tanggal 27 Juni 2020 pasien mengalami penurunan kesadaran sejak 3 hari, kejang sebanyak $2 x$ selama 1 menit demam sejak 1 hari yang lalu dan dibawa ke IGD RSUP Sanglah. Pasien lalu dilakukan CT Scan Kepala dengan dan tanpa kontras dengan kesan: Non communicating hydrocephalus disertai dengan edema transependymal kesan Non communicating hydrocephalus disertai dengan edema transependymal (kesan bertambah dibandingkan dengan MRI sebelumnya) ec penekanan ventrikel III oleh massa regio pineal. Edema cerebri dengan cooper beaten skull (Gambar 4). Massa intrabulbus oculi kanan yang meluas ke nervus optikus kanan hingga suprasellar dan parasellar, sangat mungkin suatu trilateral retinoblastoma. Tak tampak massa pada intrabulbus oculi kiri. Saat ini tak tampak gambaran meningitis. Pasien oleh TS Bedah Saraf didiagnosa dengan Hidrosefalus non komunikan + susp Meningitis bacterial dd/ viral + edema cerebrii tipe vasogenic + Optic Pathway glioma dd/ polycystic astrositoma.

Tanggal 28 Juni 2020 pasien direncanakan untuk konsul ke TS Pediatri dan dilakukan External Ventricular Drain Kocher Sinistra dengan General Anestesi di Ruang Operasi IGD oleh TS Bedah Saraf. TS Pediatri mendiagnosa pasien dengan Protein energi malnutrisi berat + susp eningitis bacterial $\mathrm{dd} /$ virus + observasi penurunan kesadaran ec hidrosefalus non komunikans dan edema cerebrii ec optic pathway glioma $\mathrm{dd} /$ polycystic astrositoma 

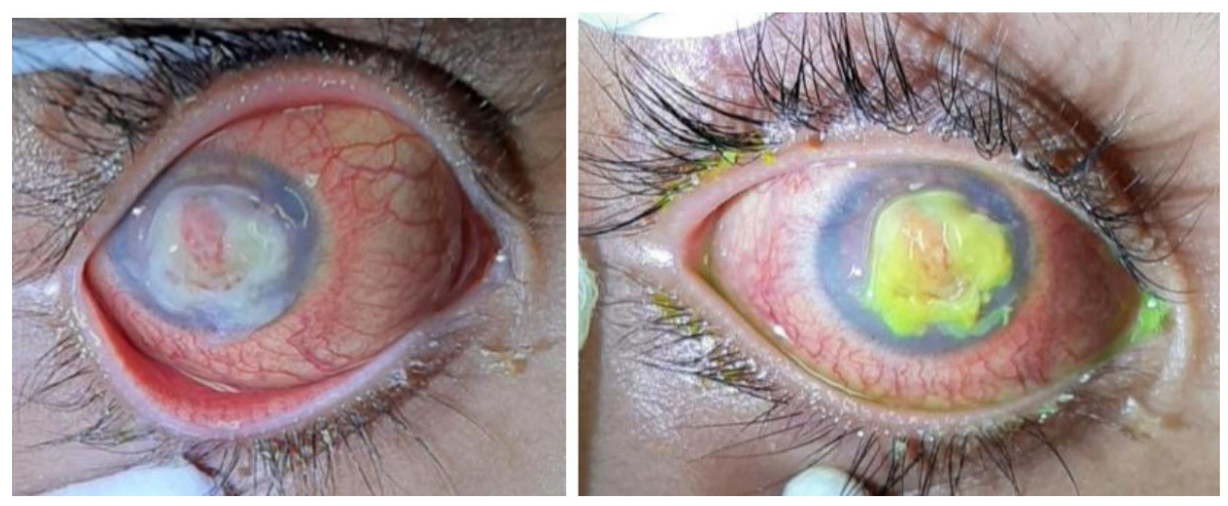

Gambar 6. Penampang mata pasien saat dirawat di PICU dengan ditemukannya ulkus terepitelisasi di mata kanan.
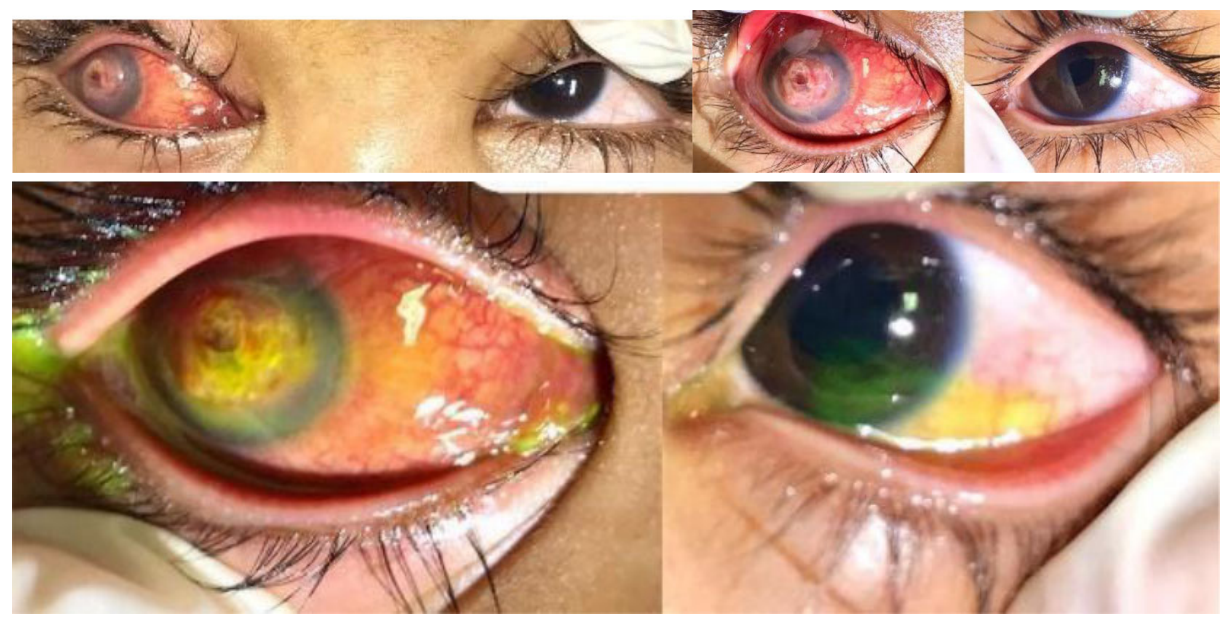

Gambar 7. Pemeriksaan mata terakhir yang dilakukan tanggal 31 Juli 2020 didapatkan kondisi ulkus kornea mata kanan terepitelisasi dan didapatkan keratitis exposure pada mata kiri dikarenakan lagoftalmos.

+ mikrosefali + PDP Covid-19. Setelah operasi pasien dirawat di Bangsal Isolasi Kamboja. Pasien dipindahkan ke Ruang Intensif Pediatri (PICU) setelah hasil dua kali Swab PCR negative.

Tanggal 20 Juli 2020 pasien dikonsulkan kembali oleh departemen pediatric dengan perburukan kondisi dan pasien dirawat di PICU dengan diagnosa Syok sepsis, ARDS, Gagal Nafas, Hospital acquired pneumonia, Hidrosefalus non komuniman ec optic pathway glioma $\mathrm{dd} /$ astrositoma polikistik post EVD shunt, imbalans elektrolit (hiponatremia, hipokalemia), suspek Syndrome of Inappropriate Antdiuretic Hormon Secretion (SIADH), malnutrisi energy protein sedang, anemia sedang normokromik normositer ec trombositopenia berat, dan ulkus pedis dextra dengan terapi Meropenem 40mg/ $\mathrm{kg} / \mathrm{x}$ dalam $20 \mathrm{ml} \mathrm{NS}$ habis dalam 3-4 jam tiap 8 jam, Epinefrin $9 \mathrm{mg}$ dalam 25 $\mathrm{ml} \mathrm{Nacl} 0.9 \%$, Omeprazole $15 \mathrm{mg}$ tiap 12 jam, Transfusi PRC 2x200 ml target $\mathrm{Hb}$ 12, Parasetamol 150mg tiap 4 jam bila suhu $38^{\circ} \mathrm{c}$. dari heteroanamensis ibu pasien, dikatakan reseksi tumor dijadwalkan dengan operasi gabungan departemen mata dan bedah saraf harus ditunda karena keadaan umum pasien yang kurang baik. Departemen bedah saraf merencanakan observasi hingga keadaan umum pasien membaik dan jika memungkinan melakukan kraniotomi tumor removal. Luka kronis regio cruris dextra dirawat oleh departemen bedah plastik dengan perawatan luka dengan wound gel + tulle + kassa steril setiap 2-3 hari, mobilisasi dilakukan setiap 2 jam dan dirawat menggunakan kasur angin.

Pada pemeriksaan didapatkan GCS E3V1M1 sehingga pemeriksaan visus tidak dapat dilakukan. Pada pemeriksaan segmen anterior didapatkan lagoftalmos pada kedua mata $1 \mathrm{~cm}$, terdapat injeksi konjungtiva dan perikornea pada konjungtiva mata kanan serta subconjunctival bleeding pada mata kiri. Pemeriksaan kornea mata kanan menunjukkan fluorescin positif dengan adanya ulkus di area sentral, ukuran 9x6 mm, dasar bersih, batas tegas, tidak didapatkan lesi satelit, terepitelisasi, seidel test (-), dan didapatkan neovaskularisasi. Bilik mata depan kesan dangkal dan didapatkan neovaskularisasi. Segmen anterior lain dan posterior tidak dapat diperiksa. Pada mata kiri, didapatkan middilatasi dengan ukuran $6 \mathrm{~mm}$, reflex langsung dan tak langsung (+) menurun, segmen anterior lain dalam batas normal. Pada pemeriksaan segmen posterior didapatkan papil nervus optic batas kabur, cdr sulit dievaluasi, retina kesan baik, reflex makula menurun dengan macular star. Pasien didagnosa dengan OD proptosis ec tumor retrobulbar suspek glioma nervus optik yg berasal/ meluas ke chiasma / cerebri + ulkus kornea terepitelisasi, OS Papil edema ec massa intracranial, dan ODS Lagofthalmus. Rencana tindak lanjut observasi dan pemberian levofloksasin tetes mata 6 kali sehari di mata kanan, air mata buatan dengan dosis 6 kali sehari pada kedua mata, dan salep mata lubrikan dengan dosis 3 kali sehari (Gambar 5 dan 6).

Follow-up tanggal 31 Juli 2020 didapatkan kondisi pasien yang masih sama dengan adanya keratitis exposure di daerah inferior dikarenakan lagoftlamos pada mata kiri. Pasien diberikan tarsorafi temporer pada kedua mata dengan tambahan gentamisin salep mata 3 kali sehari di kedua mata serta dilakukan evaluasi setiap 3 hari (Gambar 7).

Pasien dinyatakan meninggal pada 1 Agustus 2020 pukul 20.00 dengan penyebab langsung syok sepsis, penyebab antara sepsis et causa Strenopomonas malthophilia dan Pseudomonas aeruginosa, ARDS, Gagal nafas tipe I, penyebab dasar hospital acquired pneumonia, dan penyebablain hidrosefalus non komunikans et causa optic pathway glioma dan pilocytic astrocytoma post EVD shunt, OD proptosis non axial et causa tumor ekstraokuler, OS optic disc swelling 
et causa infiltrasi massa tumor, imbalans elektrolit (hiponatremia, hipokalemia) suspek SIADH, PEM sedang, anemia sedang normokromik normositer et causa penyakit kronis, trombositopenia berat, ulkus pedis, hypoalbuminemia.

\section{PEMBAHASAN}

Neurofibromatosis (NF) merupakan kelainan genetic yang sering terjadi dan diturunkan secara autosomal dominan. ${ }^{5}$ Neurofibroma merupakan kelompok kanker heterogenik yang diturunkan. Neurofibroma dapat menyebabkan tumor pada sistem saraf pusat ataupun system saraf perifer. Terdapat 3 jenis NF yang sering ditemui antara lain NF-1(96\%), NF-2 (3\%), dan yang paling jarang adalah Schwannomatosis. ${ }^{6}$

Neurofibromatosis tipe 1 sering disebut dengan penyakit Von Recklinghausen atau peripheral neurofibromatosis. Neurofibromatosis 1 merupakan kelainan neurocutaneous yang diturunkan. ${ }^{7}$ Neurofibromatosis 1 disebabkan oleh gen neurofibromin suppressor yang terdapat pada kromosom 17. Tumor multisystem pada kulit dan system saraf pusat menjadi karakteristiknya dimana tumor ini bisa berubah menjadi malignant. Gejala klinisnya antara lain multiple café au lait, neurofibromas, intertrigonus freckling, lesi osseous, lisch nodules dan Glioma Saraf Optik (GSO). Neurofibroma tipe 2 memiliki nama lalin yaitu bilateral acoustic neurofibromatosis atau central neurofibromatosis. Neurofibromatosis 2 merupakan sebuah sindroma tumor yang diturunkan dengan karakteristik lebih dominan pada pembentukan dari schwanomas, meningiomas, ependymomas, dan kelainan mata. Neurofibromatosis 2 diturunkan secara autosomal dominan dan disebabkan oleh mutase dari gen NF2 pada kromosom $22{ }^{8,9}$ Schwannomatosis adalah sebuah sindrom dengan karakteristik adanya peripheral nerve schwannomas multiple tanpa ada keterlibatan dari nervus vestibular. Schwannomatosis merupakan predominant tumor pada NF2 dan schwannomatosis, sehingga bisa terjadi overlap pada fenotip kedua sindrom ini. Namun secara genetic, kedua sindrom ini merupakan suatu hal yang berbeda. Schwannomatosis disebabkan oleh mutase dari gen SMARCB1 pada kromosom $22 \mathrm{q} 11.2 .^{6}$

Glioma Saraf Optik merupakan tumor otak primer yang paling banyak terjadi pada 1 dekade kehidupan. ${ }^{1}$ GSO merupakan low-grade glioma yang bisa berinfiltrasi ke nervus optikus, chiasma optikus, tractus optikus, dan hipotalamus. GSO terjadi pada awal masa anak-anak dengan kecenderungan terjadi pada usia 3-5 tahun. Lima persen kejadian tumor intracranial pada anak-anak merupakan GSO. Anak-anak yang didiagnosa dengan GSO memiliki neurofibromatosis tipe 1 (NF-1) yang timbul secara sporadis. ${ }^{1}$ Anak dan orang dewasa dengan NF-1 cenderung untuk memiliki tumor pada central nervous systems. Sebanyak 2-3 glioma ditemukan pada optic pathway, brainstem (15-20\%), cerebellum ( 5\%), cerebral hemispheres $(\sim 5 \%)$ dan struktur subcortical $(\sim 5 \%){ }^{10}$

Glioma Saraf Optik memiliki gejala penurunan penglihatan tanpa adanya rasa nyeri yang dirasakan perlahan. Penurunan penglihatan ini termasuk tajam penglihatan, lapang pandang, kontras dan penglihatan warna. ${ }^{2}$ Gangguan gerak bola mata terjadi pada $30 \%$ kasus GSO, selain itu pasien akan mengeluh nyeri kepala, kejang, mual muntah, pertumbuhan yang terhambat dan retardasi mental. ${ }^{1}$

Pasien seorang anak perempuan berusia tujuh tahun datang ke poli mata dikeluhkan kedua mata tidak dapat melihat. Mata kanan tidak dapat melihat sejak 1 tahun sebelum dilakukan pemeriksaan, kabur bersifat perlahan, hingga akhirnya tidak dapat melihat sama sekali. Awalnya mata kanan sempat merah dan terlihat ada bintik putih di bagian tengah mata. Mata kanan menonjol sejak 3 bulan yang lalu, dan mata kiri dikatakan mulai kabur sejak 3 minggu yang lalu. Riwiyat nyeri kepala sering dikeluhkan oleh pasien di seluruh kepala. Mual muntah kadang-kadang dirasakan.

Lokasi tumor mempengaruhi gejala klinis yang muncul antra lain adanya unilateral proptosis, penurunan tajam penglihatan, gangguan lapang pandang, strabismus, adanya RAPD dan optic disc edema atau atrofi. Masa pada hipotalamus dapat menyebabkan hidrosefalus obstruktif sehingga menyebabkan nyeri kepala dan mual. ${ }^{10}$
Hasil pemeriksaan fisik pasien pada tanggal 2 Juni 2020 di poli mata divisi pediatric oftalmologi didapatkan visus kedua mata no light perception (NLP). Pemeriksaan segmen anterior kedua mata didapatkan proptosis dengan scleral show dan lagoftalmos $2 \mathrm{~mm}$ pada mata kanan, sedangkan palpebra kiri normal. Konjungtiva mata kanan didapatkan injeksi perikornea dengan edema kornea dengan gambaran hemosiderin. Tekanan intraokular mata kanan $47 \mathrm{mmHg}$. Middilatasi dengan penurunan reflex pupil pada mata kiri dengan lensa jernih dan pada pemeriksaan segmen posterior didapatkan papil nervus optik batas kabur, cup-disc ratio (CDR) sulit dievaluasi, retina kesan baik, reflex makula menurun dengan gambaran macular star.

Gambaran CT Scan pada pasien dengan GSO didapatkan lesi iso-hipointens dengan pembesaran yang fusiform pada nervus optikus dan didapatkan kinking atau turtousity. CT Scan juga bisa menilai adanya erosi dan pembesaran dari canalis optikus dan jarang ditemukan kalsifikasi. MRI menjadi modalitas pilihan apabila untuk menilai perluasan pada kiasma optikus, intracranial, hipotalamus. ${ }^{11,12}$ Gambaran MRI biasanya ditemukan hipo-iso intens pada T1 dan hiperintens pada T2. Gambaran massa dengan batas tegas, gambaran fusiform, serta terkadang didapatkan tortous atau kinking dari nervus optikus bisa ditemukan apabila terdapat lesi pada nervus optikus. Gambaran MRI untuk lesi pada kiasma optikus dilaporkan memiliki gambaran yang beragam, mulai dari pembesaran yang nonenhancing dari kiasma hingga gambaran lesi bulky suprasellar enhancing dengan/tanpa adanya komponen exophytic. Ukuran dari GSO dilaporkan bervariasi, pada bayi dan anak-anak dikatakan cenderung memiliki tumor yang lebih besar. Hidrosefalus bisa terjadi apabila didapatkan tumor berukuran besar dan menghambat aliran cairan cerebrospinal. ${ }^{12}$

Hasil MRI kepala pasien didapatkan tubular enlarge lesion pada nervus optikus kanan sampai kiasma optikum, supra selar dan hypothalamus, yang tampak hipo-isointense pada T1WI, hyperintense sedikit pada T2WI, isointense pada fat sat, berukuran sekitar $4,6 \times 3,8 \times 4,4$ $\mathrm{cm}$ dengan komponen kistik minimal 
dengan penyangatan kontras kuat, tampak perluasan ke intraorbita, menekan ventrikel III. Tampak dilatasi dari ventrikel lateral disertai periventrikel cerebral edema. Tampak pula gambaran lesi isointense TIWI, hiperintense sedikit pada T2WI yang menyangat yang mengesankan adanya perpanjangan massa jaringan lunak nervus opticus dextra - kiasma optikum -hypothalamic, meluas sampai intraorbita dextra menyebabkan proptosis bulbus occuli dextra, menekan ventrikel I menyebabkan hydrocephalus obstruktif disertai edema periventrikel, mengarah pada optic pathway glioma $\mathrm{dd} /$ pylocytic astrocytoma dan suspek perluasan ke regio internal auditory canal dextra.

Tatalaksana dari GSO antara lain observasi, pembedahan, kemoterapi dan radioterapi. Tidak didapatkan consensus pada tatalaksana pembedahan. Reseksi total hanya mungkin dilakukan apabila tumor sudah mendesak nervus optikus dan adanya kebutaan. ${ }^{11}$ Biopsy untuk tujuan mendiagnosis penyakit, saat ini sudah ditinggalkan. Reseksi tumor dilakukan apabila terdapat proptosis yang berat dan didapatkan nyeri atau menyebar ke posterior hingga mengancam keterlibatan dari kiasma optikus. ${ }^{1} \quad$ Pembedahan yang agresif pada pasien dengan glioma kiasma yang besar dikatakan sulit untuk dilakukan. Pembedahan radikal juga memiliki resiko kerusakan dari visual apparatus, hipotalamus dan struktur vascular. ${ }^{11}$ Pengangkatan tumor dilakukan melalui trans-orbital approach dengan menjaga bola mata serta extraocular muscle sehingga menghasilkan hasil kosmetik yang baik. ${ }^{1}$ Reseksi tumor dengan keterlibatan intracranial atau intracanalicular dan dilakukan reseksi pada sepanjang nervus optikus untuk mencegah perluasan. ${ }^{13,14}$

Pasien didiagnosa dengan OD proptosis ec tumor retrobulber susp glioma nervus optik yg berasal dari chiasma / cerebri + perdarahan vitreus + glaukoma sekunder, OS Papil edema ec masa intracranial. Pasien direncanakan OD extended enukleasi join op TS Bedah Saraf dengan Tindakan Tumor Removal. Namun pasien belum sempat dilakukan operasi dikarenakan keadaan umum pasien memburuk dan meninggal pada tanggal 1 Agustus 2020.

\section{SIMPULAN}

Glioma yang mengenai jalur optik merupakan tumor jinak yang biasanya tidak membahayakan nyawa. Namun, komplikasi yang disebabkan oleh adanya paparan massa tumor dapat meningkatkan risiko infeksi yang menyebabkan risiko kematian dengan berkembangnya syok sepsis. Masa perawatan di rumah sakit serta waktu tunggu operasi dapat menjadi salah satu penyebab terjadinya infeksi yang berujung pada sepsis dan menyebabkan kematian. Penanganan yang baik dan kerjasama multidisiplin dalam penegakan diagnosis dan tatalaksana massa intraocular maupun intracranial dibutuhkan untuk memberikan luaran yang baik bagi pasien.

\section{KONFLIK KEPENTINGAN}

Penulis meyatakan tidak terdapat konflik kepentingan terkait publikasi dari laporan kasus ini.

\section{PENDANAAN}

Penulis tidak mendapatkan dana untuk terkait publikasi dari laporan kasus ini baik dari pemerintah maupun sektor swasta.

\section{KONTRIBUSI PENULIS}

Seluruh penulis telah ikut serta dalam penyusunan naskah publikasi laporan kasus dan setuju terhadap versi final dari naskah untuk dilakukan publikasi.

\section{ETIKA DALAM PENELITIAN}

Penelitian ini telah mendapatkan kelayakan etik dari Komite Etik Fakultas Kedoktera Universitas Udayana/RSUP Sanglah Denpasar, Bali, Indonesia dengan nomer kelayakan etik 1378/ UN14.2.2.VII.14/LT/2021. Orang tua dari pasien telah menandatangani lembar persetujuan (informed consent) terkait publikasi dari data medis dalam laporan kasus kedokteran.

\section{DAFTAR PUSTAKA}

1. Huang M, Patel J, Patel BC. Optic Nerve Glioma. In: Definitions. Qeios; 2020. Available from: http://dx.doi.org/10.32388/977d2o

2. Drimtzias E, Picton S, Richards D, Falzon K, Hoole J, Simmons I. LG-28 threat to vision score (ttv score) in children with optic pathway gliomas (opgs): uk experience from prospective low grade glioma (lgg2) trial. Neuro Oncol. 2016;18(suppl 3):iii85.1-iii85. Available from: http://dx.doi.org/10.1093/neuonc/now075.28

3. Katz B. Neuro-Ophthalmology: Section 5, Basic and Clinical Science Course. J NeuroOphthalmology. 2002;22(2):147. Available from: http://dx.doi.org/10.1097/00041327200206000-00053

4. van Baarsen K, Roth J, Serova N, Packer RJ, Shofty B, Thomale UW, Cinalli G, Toledano H, Michowiz S, Constantini S. Optic pathwayhypothalamic glioma hemorrhage: a series of 9 patients and review of the literature. J Neurosurg.129(6):1407-1415. Available from: doi: 10.3171/2017.8.JNS163085. PMID: 29424646

5. Gerber PA, Antal AS, Neumann NJ, Homey B, Matuschek C, Peiper M, et al. Neurofibromatosis. Eur J Med Res. 2009;14(3):102-5. Available from: gov/19380279

6. Kresak JL, Walsh M. Neurofibromatosis: A Review of NF1, NF2, and Schwannomatosis. J Pediatr Genet. 2016/03/09. 2016;5(2):98-104. Available from: https://pubmed.ncbi.nlm.nih. gov/27617150

7. Cassina M, Frizziero L, Opocher E, Parrozzani R, Sorrentino U, Viscardi E, et al. Optic Pathway Glioma in Type 1 Neurofibromatosis: Review of Its Pathogenesis, Diagnostic Assessment, and Treatment Recommendations. Cancers (Basel). 2019;11(11):1790. Available from: https:// pubmed.ncbi.nlm.nih.gov/31739524

8. Karaconji T, Whist, E, Jamieson R, Flaherty M, Grigg J. Neurofibromatosis Type 1: Review and Update on Emerging Therapies. Asia-Pacific J Ophthalmol. 2019; Available from: http:// dx.doi.org/10.22608/apo.2018182

9. Coy S, Rashid R, Stemmer-Rachamimov A, Santagata S. An update on the CNS manifestations of neurofibromatosis type 2 . Acta Neuropathol. 2019/06/04. 2020;139(4):643-65. Available from: https://pubmed.ncbi.nlm.nih. gov/31161239

10. Campen CJ, Gutmann DH. Optic Pathway Gliomas in Neurofibromatosis Type 1. J Child Neurol. 2018;33(1):73-81. Available from: https://pubmed.ncbi.nlm.nih.gov/29246098

11. Fried I, Tabori U, Tihan T, Reginald A, Bouffet E. Optic pathway gliomas: a review. CNS Oncol. 2013;2(2):143-59. Available from: https:// pubmed.ncbi.nlm.nih.gov/25057976

12. Nair AG, Pathak RS, Iyer VR, Gandhi RA. Optic nerve glioma: an update. Int Ophthalmol. 2014;34(4):999-1005. Available from: http:// dx.doi.org/10.1007/s10792-014-9942-8 
13. Farazdaghi MK, Katowitz WR, Avery RA. Current treatment of optic nerve gliomas. Curr Opin Ophthalmol. 2019;30(5):356-63. Available from: https://pubmed.ncbi.nlm.nih. gov/31246635
14. Eghtedari M, Fattahi SF, Owji N, Ashraf MJ, Khalili MR, Geramizadeh B. Optic nerve glioma with complete intraocular extension. J Curr Ophthalmol. 2016;28(4):228-31.
Available from: https://pubmed.ncbi.nlm.nih. gov/27830210

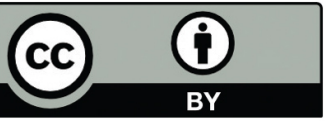

This work is licensed under a Creative Commons Attribution 